American Journal of Infectious Diseases 3 (2): 115-122, 2007

ISSN 1553-6203

(C) 2007 Science Publications

\title{
A Novel Heat Shock Transcription Factor Family in Entamoeba histolytica
}

\author{
Consuelo Gómez García, Ma. de la Luz Macias Argüelles, D. Guillermo Pérez Ishiwara, Mariela Suárez \\ Tecla, Alma Nieto Martínez, Olivia Medel Flores, Ricardo Orozco Solís and Elvira Náder García \\ Institutional Program of Molecular Biomedicine, ENMyH-IPN. Guillermo Massieu Helguera No. 239. \\ Fracc. "La Escalera”, Ticomán, CP 07320, México City, México
}

\begin{abstract}
The HSTF is a master molecule involved in the transcriptional control of several genes during different types of stress. This transcription factor is a very conserved protein identified in different organisms from bacterial to human. Entamoeba histolytica is the protozoan responsible for the human amoebiasis. This parasite is exposed to different kind of stress as changes in the $\mathrm{pH}$, temperature, drugs, all that situations in where the parasite needs survive. Here we identified and isolated a novel gene family of HSTFs in the protozoan parasite $E$. histolytica. Three members that we called Ehhstfl, Ehhstf 2 and Ehhstf3 compose this family. Amino acid alignments and domain architecture analysis revealed that the EhHSTFs presents a conserved DNA-binding domain composed of approximately 25 residues. Interestingly this domain is shorter than the domain of the human, mouse and yeast HSTFs. Heterologous antibodies recognized four peptides of 73, 66, 47 and $23 \mathrm{kDa}$ in total extracts from trophozoites growth under normal conditions. The 73, 47 and $23 \mathrm{kDa}$ peptides increased their intensity when the cells were growth at $42^{\circ} \mathrm{C}$ by $2 \mathrm{~h}$. All results together demonstrate that the amoeba present HSTFs, which may be, controlled the gene expression of this parasite under different stress situations.
\end{abstract}

Key words: heat shock, HSTF, amoebiasis, transcription factor

\section{INTRODUCTION}

All the organisms respond to chemical, environmental or physiological stress through a transient arrest of the cell cycle that is accompanied by widespread changes in macromolecular synthesis, degradation, trafficking, overall cellular metabolism and signal transduction pathways to cope with stressful conditions until more favourable conditions are encountered [1].

The termic stress in any organism may provoke different changes, since expression and/or repression of different molecules, the destabilization of protein conformation, leading to protein unfolding and aggregation, until severe or prolonged stresses can lead irreversible protein damage provoking the cell die [2]. The heat shock stress is one of the must studied mechanisms from bacteria to mammal cells. A very knows group of proteins have been completely related to this event: the heat shock proteins (Hsps). These proteins are chaperones involved in the folding, trafficking, maturation and degradation of proteins [3]. Additionally, other important proteins involved in the heat shock response are the heat shock transcription factors (HSTF), which rapidly activate and bind to the heat shock element (HSE) present in the Hsp promoters. Then this factor induces the Hsps gene expression whose products ensure the survival of the cell during stressful conditions by providing defense against general protein damage [4].

Although the heat shock response is conserved among eukaryotes, both the number and overall sequence of HSTFs vary widely among different species. Yeast as Saccharomyces cerevisiae, Schizosaccharomyces pombe and Kluyveromyces lactis and in the fruit fly as Drosophila melanogaster appear to have a single $h s t f$ gene, most vertebrates and higher plants possess multiple $h s t f$ genes: at least three hstf genes have been isolated from human, mouse, chicken and tomato genomes, whereas Arabidopsis thailiana has 21 hstf genes [5-15].

Little is known about transcriptional control of its genes in Entamoeba histolytica, the parasite that causes amebic dysentery. Just four promoters from the EhPgp1, EhPgp5, hgl5 and actin genes have been functionally characterized and until this moment have been functionally described the TATA box, the CAAT/enhancer binding elements, the GAACT and the

Corresponding Author: Consuelo Gómez García, PhD. Institutional Program of Molecular Biomedicine, ENMyH-IPN. Guillermo Massieu Helguera No. 239. Fracc. "La Escalera”, Ticomán, CP 07320, México City, México. Tel-fax (55)55864741; 
UREs sequences [16-24]. With respect to the transcription factors have been reported the sequences for the TATA box binding protein (TBP) [25], two enhancer binding proteins (EhEBP1 and EhEBP2) that binds to the URE4 sequence [26] and the p53 [27] and $\mathrm{C} / \mathrm{EBP}$-like proteins (personal communication).

Recently, in the multidrug resistance EhPgp5 gene promoter from E. histolytica Nieto and coworkers identified a functional putative heat shock response element (HSE) 'unpublished data' suggesting that in this parasite will be present a HSTF. In this work, we performed the screening and isolation of a novel heat shock transcription factors from the amoeba.

\section{METHODS}

E. histolytica strain: Trophozoites of clone A from the pathogenic E. histolytica strain HM-1:IMSS were axenically cultured in TY1-S-33 medium [28]. For heat shock treatment, trophozoites cultured in Diamond's TYI-S-33 medium were incubated at $42^{\circ} \mathrm{C}$ for 30,60 and $120 \mathrm{~min}$.

Identification of a conserved domain in the HSTF from different organisms: HSTF genomic sequences were obtained from the GenBank and Sanger databases. Sequences alignments of the eukaryotic HSTFs were performed using ClustalW with gap penalties of 10 (http://www.ch.embnet.org/software/ClustalW.html).

Isolation of the Ehhstf genes from the $E$. histolytica project genome: Conserved sequence of the Human HSTF corresponding to the DNA binding domain (106 aa) was used to screen the E. histolytica databases: Sanger servers (http://www.sanger.ac.uk/Projects/E_histolytica/) and TIGR (http://www.tirg.org/tdb/e2k1/eha1/) using TBLASTN 2.0 program. To determine significant e values and identity-homology percentages, aa sequences were compared with Homo sapiens (Q00613), Mus musculus (P38532), Gallus gallus (P38529), Xenopus laevis (P41154), D. melanogaster (P22813), K. lactis (P22121), S. cerevisiae (P10961) and $A$. thailiana (P41151) related proteins using BLAST.

The molecular weight of the proteins was obtained from the ExPASy Server (http://cn.expasy.org). A neighbor Joining tree was constructed with 500 bootstrap replications using the program PHYLO_WIN.

Cloning and sequencing of the Ehhstf genes: The Ehhstf1, Ehhstf2 and Ehhstf3 genes were isolated by PCR using the sense and antisense primers Eh1S (5'CGGGATCCATGAGGTGGTGTGATGAA-3'), Eh1As (5'-GGGGTACCTTCCCAAGGATTCATTCC-
3'), Eh2S (5'-

CGGGATCCATGGAGAATAAAGATA-3'), Eh2As (5'-GGGGTACCCCTTTCAGTTTTTTGTTC-3'), Eh3S (5'-CGGGATCCATGGCAATGGAAATCCC$\left.3^{\prime}\right)$ and Eh3As (5'-

GGGGTACCTTCATTTAAAAACAAAAC-3')

respectively and total DNA from clone A trophozoites.

Protein Analysis: Briefly, trophozoites were washed twice, resuspended at $10^{6} / \mathrm{ml}$ of phosphate-buffered saline (PBS) and then were disrupted by repeated freezing and thawing in liquid nitrogen. Extracts were centrifuged at $180 \mathrm{xg}$ for $5 \mathrm{~min}$ at $4^{\circ} \mathrm{C}$, then, the supernatants were separated on $12 \%$ SDSpolyacrilamide gel. The proteins were blotted onto Hybond-C (Amersham, Little Chalfont, UK) membrane. Filters were blocked with milk and incubated overnight with antisera to human HSF1 (H311, Santa Cruz), human C/EBP $\beta$ ( $\Delta$ 198, Santa Cruz) and $E$. histolytica actin. Then, the bound antibody was detected with horseradish peroxidase-conjugated antirabbit immunoglobulin (Zymed) for the HSTF and $\mathrm{C} / \mathrm{EBP}$ proteins and anti-mouse immunoglobulin (Zymed) for actin protein. Immunoblots were revealed with 4-Cl-naphtol. Protein concentration was determined using the Bradford method [29].

\section{RESULTS}

To identify a conserved sequences in the HSTFs, first, we aligned eight amonoacid hstf genes sequences from $H$. sapiens, M. musculus, G. gallus, $X$. laevis, D. melanogaster, K. lactis, $S$. cerevisiae and $A$. thailiana using the CLUSTALW program. The multiple alignments showed the presence of a conserved sequence of approximately 106 aa, that corresponds to the DNA-binding domain located at the amino terminal of the proteins (data not shown). Additionally, we identified the hydrophobic repeats $\mathrm{HR}-\mathrm{A} / \mathrm{B}$ in the carboxi-terminal of the human, mouse, chicken and frog HSTF aa sequences and the hydrophobic repeats HR-C only in the human, mouse and chicken genes (data not shown).

In order to identify if E. histolytica contains the hstf genes in its genome, we performed a screening using the DNA-binding domain of the human hstfl sequence (106 aa) (sp/Q00613/HSF1_HUMAN) as probe in the Sequentiation Project Genome TIGR from the amoeba and the Sanger site (www.sanger.ac.uk/projects/E_histolytica) using the TBLASTN 2.0 program.

At least 14 contings were detected, however the contings 2390555.c000134323.conting3, 2390555.c000721893.conting3 and 2390555.c000721829.conting5 presented the major 
homology and identity percentages with the human HSTF1 (Table 1). When we carried out the in silico analysis of the conting 2390555.c000134323.conting3, we identified an open reading frame of $510 \mathrm{pb}$, corresponding to 170 aa and generated a protein of predicted molecular weight of $20.44 \mathrm{kDa}$. We call this sequence Ehhstfl gene.

In the conting 2390555.c000721893.conting3, we located a gene of $837 \mathrm{bp}$, that encode to protein of 279 aa and its molecular mass obtained by the Expasy program was $32 \mathrm{kDa}$. The name of this gene is Ehhstf2. The third conting (2390555.c000721829.conting5) contains a gene of 459 nucleotides that encode a polypeptide of 153 aa, the predicted molecular weight was of $17.59 \mathrm{kDa}$ and it was called Ehhstf3 gene.

In order to determine more precisely the identity of each one of the Ehhstf genes, we carried out multiple alignments of each Ehhstf aa sequences with the HSTFs of different organisms using the BLASTX program and the DNA-binding domain or the complete sequence of the genes. The results showed that the EhHSTF2 and EhHSTF3 present major identity and homology percentages with the different HSTF sequences (Table 2) than the EhHSTF1. However, the EhHSTF1 presents percentages further up $24 \%$ of identity and $37 \%$ of homology with the DNA-binding domain of different HSTFs (Table 2). In contrast, when we performed the alignments using the completed HSTF sequences the identity and homology percentages presented by the EhHSTFs were very low in comparison with the percentages observed for the HsHSTF or the MmHSTF between others (Table 3). Something similar we can observed with the A. thailiana hstf genes, because low values of identity and homology were obtained, particularly with the Athstf4 (Tables 2 and 3).

Table 1: Identification of E. histolytica secuences similar to the HSTF

\begin{tabular}{ccc}
\hline Conting & Identity (\%) & Homology (\%) \\
\hline 2390555.c000721893.Conting3 & 34 & 52 \\
2390555.c000721829.Conting5 & 52 & 74 \\
2390555.c000134323.Conting3 & 33 & 54 \\
\hline
\end{tabular}

The alignment of the EhHSTF with the HSTFs of different organisms showed that the region with major similitude between these sequences corresponds to the DNA-binding domain as we mentioned above (Fig 1). Interestingly, the size of this domain is smallest in the three EhHSTFs than in the other HSTF sequences, because it is conformed by 25 conserved aa instead of the 106 aa of the human, mouse and chicken domains between others (Fig 1 and 2). In addition, we observed six aa changes in these domain: one of them correspond to the third aa which is different in the three EhHSTF sequences; other three changes are located in the fourth, eighth and tenth amino acids only in the EhHSTF1, and two aa more at 11 and 25 positions are changed just in the EhHSTF2 (Fig 2).

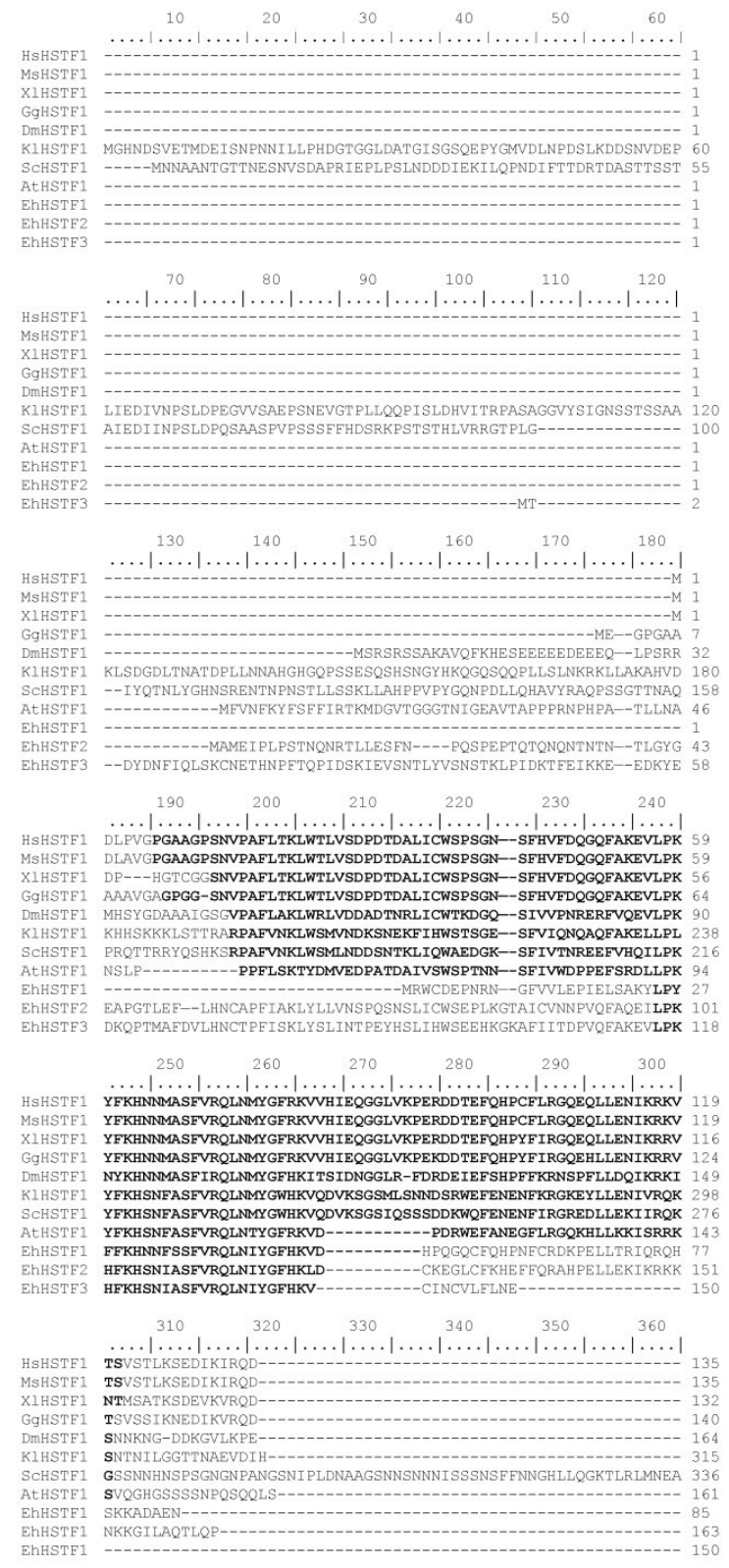

Fig 1: Alignment of the amino acid sequences of $H$. sapiens, M. musculus, X. laevis, G. gallus, D. melanogaster, $K$. lactis, $S$. cerevisiae, A. thailiana with the E. histolytica HSTFs. All accession numbers are from the GenBank database. The DNA-binding domain is in bold face. 
Am. J. Infect. Dis., 3 (2): 115-122, 2007

Table 2: Amino acid identities among the DNA-binding domain of the EhHSTFs and closely related homologues from other organisms.

\begin{tabular}{|c|c|c|c|c|c|c|c|c|c|c|c|c|c|c|c|}
\hline & EhHSTF1 & EhHSTF2 & EhHSTF3 & HsHSTF1 & HsHSTF2 & HsHSTF4 & GgHSTF1 & GgHSTF2 & GgHSTF3 & MmHSTF1 & MmHSTF2 & MmHSTF 4 & AtHSTF1 & AtHSTF3 & AtHSTF4 \\
\hline EhHSTF1 & $\begin{array}{r}100 \% \\
0 \%\end{array}$ & & & & & & & & & & & & & & \\
\hline EhHSTF2 & $\begin{array}{l}26 \% \\
39 \%\end{array}$ & $\begin{array}{r}100 \% \\
0 \%\end{array}$ & & & & & & & & & & & & & \\
\hline EhHSTF3 & $\begin{array}{l}28 \% \\
41 \%\end{array}$ & $\begin{array}{l}60 \% \\
78 \%\end{array}$ & $\begin{array}{r}100 \% \\
0 \%\end{array}$ & & & & & & & & & & & & \\
\hline HsHSTF1 & $\begin{array}{l}26 \% \\
40 \%\end{array}$ & $\begin{array}{l}43 \% \\
61 \%\end{array}$ & $\begin{array}{l}43 \% \\
62 \%\end{array}$ & $\begin{array}{r}100 \% \\
0 \%\end{array}$ & & & & & & & & & & & \\
\hline HsHSTF2 & $\begin{array}{l}28 \% \\
40 \%\end{array}$ & $\begin{array}{l}42 \% \\
62 \%\end{array}$ & $\begin{array}{l}40 \% \\
63 \%\end{array}$ & $\begin{array}{l}65 \% \\
80 \%\end{array}$ & $\begin{array}{r}100 \% \\
0 \%\end{array}$ & & & & & & & & & & \\
\hline HsHSTF4 & $\begin{array}{l}25 \% \\
39 \%\end{array}$ & $\begin{array}{l}40 \% \\
59 \%\end{array}$ & $\begin{array}{l}43 \% \\
59 \%\end{array}$ & $\begin{array}{l}76 \% \\
83 \%\end{array}$ & $\begin{array}{l}61 \% \\
75 \%\end{array}$ & $\begin{array}{r}100 \% \\
0 \%\end{array}$ & & & & & & & & & \\
\hline GgHSTF1 & $\begin{array}{l}26 \% \\
40 \%\end{array}$ & $\begin{array}{l}43 \% \\
61 \%\end{array}$ & $\begin{array}{l}44 \% \\
61 \%\end{array}$ & $\begin{array}{l}91 \% \\
92 \%\end{array}$ & $\begin{array}{l}65 \% \\
80 \%\end{array}$ & $\begin{array}{l}74 \% \\
81 \%\end{array}$ & $\begin{array}{r}100 \% \\
0 \%\end{array}$ & & & & & & & & \\
\hline GgHSTF2 & $\begin{array}{l}26 \% \\
37 \%\end{array}$ & $\begin{array}{l}41 \% \\
57 \%\end{array}$ & $\begin{array}{l}38 \% \\
60 \%\end{array}$ & $\begin{array}{l}58 \% \\
73 \%\end{array}$ & $\begin{array}{l}78 \% \\
84 \%\end{array}$ & $\begin{array}{l}59 \% \\
75 \%\end{array}$ & $\begin{array}{l}58 \% \\
73 \%\end{array}$ & $\begin{array}{r}100 \% \\
0 \%\end{array}$ & & & & & & & \\
\hline GgHSTF3 & $\begin{array}{l}26 \% \\
38 \%\end{array}$ & $\begin{array}{l}43 \% \\
60 \%\end{array}$ & $\begin{array}{l}41 \% \\
59 \%\end{array}$ & $\begin{array}{l}58 \% \\
76 \%\end{array}$ & $\begin{array}{l}58 \% \\
83 \%\end{array}$ & $\begin{array}{l}58 \% \\
77 \%\end{array}$ & $\begin{array}{l}57 \% \\
76 \%\end{array}$ & $\begin{array}{l}59 \% \\
78 \%\end{array}$ & $\begin{array}{r}100 \% \\
0 \%\end{array}$ & & & & & & \\
\hline MmHSTF1 & $\begin{array}{l}26 \% \\
40 \%\end{array}$ & $\begin{array}{l}43 \% \\
61 \%\end{array}$ & $\begin{array}{l}43 \% \\
62 \%\end{array}$ & $\begin{array}{l}100 \% \\
100 \%\end{array}$ & $\begin{array}{l}65 \% \\
80 \%\end{array}$ & $\begin{array}{l}76 \% \\
83 \%\end{array}$ & $\begin{array}{l}51 \% \\
72 \%\end{array}$ & $\begin{array}{l}58 \% \\
73 \%\end{array}$ & $\begin{array}{l}58 \% \\
76 \%\end{array}$ & $\begin{array}{r}100 \% \\
0 \%\end{array}$ & & & & & \\
\hline MmHSTF2 & $\begin{array}{l}28 \% \\
40 \%\end{array}$ & $\begin{array}{l}43 \% \\
62 \%\end{array}$ & $\begin{array}{l}40 \% \\
62 \%\end{array}$ & $\begin{array}{l}67 \% \\
80 \%\end{array}$ & $\begin{array}{r}97 \% \\
100 \%\end{array}$ & $\begin{array}{l}62 \% \\
75 \%\end{array}$ & $\begin{array}{l}67 \% \\
80 \%\end{array}$ & $\begin{array}{l}76 \% \\
84 \%\end{array}$ & $\begin{array}{l}61 \% \\
83 \%\end{array}$ & $\begin{array}{l}67 \% \\
80 \%\end{array}$ & $\begin{array}{r}100 \% \\
0 \%\end{array}$ & & & & \\
\hline MmHSTF4 & $\begin{array}{l}25 \% \\
39 \%\end{array}$ & $\begin{array}{l}40 \% \\
59 \%\end{array}$ & $\begin{array}{l}43 \% \\
59 \%\end{array}$ & $\begin{array}{l}76 \% \\
83 \%\end{array}$ & $\begin{array}{l}61 \% \\
75 \%\end{array}$ & $\begin{array}{l}100 \% \\
100 \%\end{array}$ & $\begin{array}{l}74 \% \\
81 \%\end{array}$ & $\begin{array}{l}59 \% \\
75 \%\end{array}$ & $\begin{array}{l}58 \% \\
77 \%\end{array}$ & $\begin{array}{l}76 \% \\
83 \%\end{array}$ & $\begin{array}{l}62 \% \\
75 \%\end{array}$ & $\begin{array}{r}100 \% \\
0 \%\end{array}$ & & & \\
\hline AtHSTF1 & $\begin{array}{l}35 \% \\
42 \%\end{array}$ & $\begin{array}{l}33 \% \\
54 \%\end{array}$ & $\begin{array}{l}35 \% \\
55 \%\end{array}$ & $\begin{array}{l}47 \% \\
61 \%\end{array}$ & $\begin{array}{l}42 \% \\
57 \%\end{array}$ & $\begin{array}{l}42 \% \\
57 \%\end{array}$ & $\begin{array}{l}46 \% \\
60 \%\end{array}$ & $\begin{array}{l}40 \% \\
57 \%\end{array}$ & $\begin{array}{l}42 \% \\
56 \%\end{array}$ & $\begin{array}{l}47 \% \\
61 \%\end{array}$ & $\begin{array}{l}42 \% \\
57 \%\end{array}$ & $\begin{array}{l}42 \% \\
57 \%\end{array}$ & $\begin{array}{r}100 \% \\
0 \%\end{array}$ & & \\
\hline AtHSTF3 & $\begin{array}{l}35 \% \\
40 \%\end{array}$ & $\begin{array}{l}31 \% \\
50 \%\end{array}$ & $\begin{array}{l}33 \% \\
50 \%\end{array}$ & $\begin{array}{l}43 \% \\
56 \%\end{array}$ & $\begin{array}{l}43 \% \\
56 \%\end{array}$ & $\begin{array}{l}41 \% \\
53 \%\end{array}$ & $\begin{array}{l}43 \% \\
57 \%\end{array}$ & $\begin{array}{l}43 \% \\
58 \%\end{array}$ & $\begin{array}{l}42 \% \\
56 \%\end{array}$ & $\begin{array}{l}43 \% \\
56 \%\end{array}$ & $\begin{array}{l}43 \% \\
56 \%\end{array}$ & $\begin{array}{l}41 \% \\
53 \%\end{array}$ & $\begin{array}{l}74 \% \\
83 \%\end{array}$ & $\begin{array}{r}100 \% \\
0 \%\end{array}$ & \\
\hline AtHSTF4 & $\begin{array}{l}30 \% \\
40 \%\end{array}$ & $\begin{array}{l}35 \% \\
55 \%\end{array}$ & $\begin{array}{l}34 \% \\
51 \%\end{array}$ & $\begin{array}{l}41 \% \\
56 \%\end{array}$ & $\begin{array}{l}38 \% \\
56 \%\end{array}$ & $\begin{array}{l}40 \% \\
53 \%\end{array}$ & $\begin{array}{l}39 \% \\
56 \%\end{array}$ & $\begin{array}{l}35 \% \\
55 \%\end{array}$ & $\begin{array}{l}43 \% \\
54 \%\end{array}$ & $\begin{array}{l}41 \% \\
56 \%\end{array}$ & $\begin{array}{l}48 \% \\
56 \%\end{array}$ & $\begin{array}{l}40 \% \\
53 \%\end{array}$ & $\begin{array}{l}59 \% \\
75 \%\end{array}$ & $\begin{array}{l}61 \% \\
74 \%\end{array}$ & $\begin{array}{r}100 \% \\
0 \%\end{array}$ \\
\hline
\end{tabular}

Table 3: Amino acid identities among the EhHSTFs and related homologues from other organisms.

\begin{tabular}{|c|c|c|c|c|c|c|c|c|c|c|c|c|c|c|c|}
\hline & EhHSTF1 & EhHSTF2 & EhHSTF3 & HsHSTF1 & HsHSTF2 & HsHSTF4 & GgHSTF1 & GgHSTF2 & GgHSTF3 & MmHSTF1 & MmHSTF2 & MmHSTF 4 & AtHSTF1 & AtHSTF3 & AtHSTF4 \\
\hline EhHSTF1 & $\begin{array}{r}100 \% \\
0 \%\end{array}$ & & & & & & & & & & & & & & \\
\hline EhHSTF2 & $\begin{array}{r}7 \% \\
13 \%\end{array}$ & $\begin{array}{r}100 \% \\
0 \%\end{array}$ & & & & & & & & & & & & & \\
\hline EhHSTF3 & $\begin{array}{r}8 \% \\
10 \%\end{array}$ & $\begin{array}{l}18 \% \\
25 \%\end{array}$ & $\begin{array}{r}100 \% \\
0 \%\end{array}$ & & & & & & & & & & & & \\
\hline HsHSTF1 & $\begin{array}{r}7 \% \\
11 \%\end{array}$ & $\begin{array}{r}7 \% \\
11 \%\end{array}$ & $\begin{array}{l}4 \% \\
6 \%\end{array}$ & $\begin{array}{r}100 \% \\
0 \%\end{array}$ & & & & & & & & & & & \\
\hline HsHSTF2 & $\begin{array}{r}6 \% \\
11 \%\end{array}$ & $\begin{array}{r}5 \% \\
11 \%\end{array}$ & $\begin{array}{l}4 \% \\
7 \%\end{array}$ & $\begin{array}{l}29 \% \\
45 \%\end{array}$ & $\begin{array}{r}100 \% \\
0 \%\end{array}$ & & & & & & & & & & \\
\hline HsHSTF4 & $\begin{array}{r}7 \% \\
12 \%\end{array}$ & $\begin{array}{r}6 \% \\
10 \%\end{array}$ & $\begin{array}{l}6 \% \\
7 \%\end{array}$ & $\begin{array}{l}36 \% \\
48 \%\end{array}$ & $\begin{array}{l}22 \% \\
36 \%\end{array}$ & $\begin{array}{r}100 \% \\
0 \%\end{array}$ & & & & & & & & & \\
\hline GgHSTF1 & $\begin{array}{r}7 \% \\
11 \%\end{array}$ & $\begin{array}{r}6 \% \\
10 \%\end{array}$ & $\begin{array}{l}5 \% \\
7 \%\end{array}$ & $\begin{array}{l}72 \% \\
81 \%\end{array}$ & $\begin{array}{l}27 \% \\
45 \%\end{array}$ & $\begin{array}{l}34 \% \\
48 \%\end{array}$ & $\begin{array}{r}100 \% \\
0 \%\end{array}$ & & & & & & & & \\
\hline GgHSTF2 & $\begin{array}{r}6 \% \\
10 \%\end{array}$ & $\begin{array}{r}6 \% \\
10 \%\end{array}$ & $\begin{array}{l}4 \% \\
7 \%\end{array}$ & $\begin{array}{l}28 \% \\
44 \%\end{array}$ & $\begin{array}{l}76 \% \\
84 \%\end{array}$ & $\begin{array}{l}23 \% \\
37 \%\end{array}$ & $\begin{array}{l}26 \% \\
43 \%\end{array}$ & $\begin{array}{r}100 \% \\
0 \%\end{array}$ & & & & & & & \\
\hline GgHSTF3 & $\begin{array}{r}7 \% \\
14 \%\end{array}$ & $\begin{array}{r}6 \% \\
12 \%\end{array}$ & $\begin{array}{l}5 \% \\
7 \%\end{array}$ & $\begin{array}{l}18 \% \\
30 \%\end{array}$ & $\begin{array}{l}16 \% \\
31 \%\end{array}$ & $\begin{array}{l}17 \% \\
31 \%\end{array}$ & $\begin{array}{l}17 \% \\
29 \%\end{array}$ & $\begin{array}{l}16 \% \\
31 \%\end{array}$ & $\begin{array}{r}100 \% \\
0 \%\end{array}$ & & & & & & \\
\hline MmHSTF1 & $\begin{array}{r}7 \% \\
11 \%\end{array}$ & $\begin{array}{r}7 \% \\
11 \%\end{array}$ & $\begin{array}{l}4 \% \\
6 \%\end{array}$ & $\begin{array}{l}89 \% \\
93 \%\end{array}$ & $\begin{array}{l}28 \% \\
44 \%\end{array}$ & $\begin{array}{l}35 \% \\
47 \%\end{array}$ & $\begin{array}{l}70 \% \\
80 \%\end{array}$ & $\begin{array}{l}27 \% \\
44 \%\end{array}$ & $\begin{array}{l}17 \% \\
28 \%\end{array}$ & $\begin{array}{r}100 \% \\
0 \%\end{array}$ & & & & & \\
\hline MmHSTF2 & $\begin{array}{r}6 \% \\
11 \%\end{array}$ & $\begin{array}{r}6 \% \\
11 \%\end{array}$ & $\begin{array}{l}4 \% \\
6 \%\end{array}$ & $\begin{array}{l}29 \% \\
44 \%\end{array}$ & $\begin{array}{l}94 \% \\
96 \%\end{array}$ & $\begin{array}{l}22 \% \\
35 \%\end{array}$ & $\begin{array}{l}28 \% \\
45 \%\end{array}$ & $\begin{array}{l}74 \% \\
82 \%\end{array}$ & $\begin{array}{l}17 \% \\
31 \%\end{array}$ & $\begin{array}{l}28 \% \\
44 \%\end{array}$ & $\begin{array}{r}100 \% \\
0 \%\end{array}$ & & & & \\
\hline MmHSTF4 & $\begin{array}{r}7 \% \\
12 \%\end{array}$ & $\begin{array}{r}6 \% \\
10 \%\end{array}$ & $\begin{array}{l}6 \% \\
7 \%\end{array}$ & $\begin{array}{l}35 \% \\
48 \%\end{array}$ & $\begin{array}{l}21 \% \\
38 \%\end{array}$ & $\begin{array}{l}86 \% \\
89 \%\end{array}$ & $\begin{array}{l}33 \% \\
48 \%\end{array}$ & $\begin{array}{l}22 \% \\
38 \%\end{array}$ & $\begin{array}{l}17 \% \\
29 \%\end{array}$ & $\begin{array}{l}34 \% \\
48 \%\end{array}$ & $\begin{array}{l}22 \% \\
37 \%\end{array}$ & $\begin{array}{r}100 \% \\
0 \%\end{array}$ & & & \\
\hline AtHSTF1 & $\begin{array}{r}7 \% \\
13 \%\end{array}$ & $\begin{array}{r}6 \% \\
13 \%\end{array}$ & $\begin{array}{l}5 \% \\
8 \%\end{array}$ & $\begin{array}{l}15 \% \\
28 \%\end{array}$ & $\begin{array}{l}13 \% \\
25 \%\end{array}$ & $\begin{array}{l}15 \% \\
28 \%\end{array}$ & $\begin{array}{l}15 \% \\
28 \%\end{array}$ & $\begin{array}{l}13 \% \\
26 \%\end{array}$ & $\begin{array}{l}13 \% \\
25 \%\end{array}$ & $\begin{array}{l}16 \% \\
29 \%\end{array}$ & $\begin{array}{l}12 \% \\
25 \%\end{array}$ & $\begin{array}{l}15 \% \\
28 \%\end{array}$ & $\begin{array}{r}100 \% \\
0 \%\end{array}$ & & \\
\hline AtHSTF3 & $\begin{array}{r}7 \% \\
12 \%\end{array}$ & $\begin{array}{r}6 \% \\
12 \%\end{array}$ & $\begin{array}{l}4 \% \\
6 \%\end{array}$ & $\begin{array}{l}15 \% \\
27 \%\end{array}$ & $\begin{array}{l}13 \% \\
26 \%\end{array}$ & $\begin{array}{l}15 \% \\
27 \%\end{array}$ & $\begin{array}{l}13 \% \\
27 \%\end{array}$ & $\begin{array}{l}14 \% \\
26 \%\end{array}$ & $\begin{array}{l}13 \% \\
26 \%\end{array}$ & $\begin{array}{l}15 \% \\
28 \%\end{array}$ & $\begin{array}{l}13 \% \\
25 \%\end{array}$ & $\begin{array}{l}15 \% \\
27 \%\end{array}$ & $\begin{array}{l}40 \% \\
54 \%\end{array}$ & $\begin{array}{r}100 \% \\
0 \%\end{array}$ & \\
\hline AtHSTF4 & $\begin{array}{l}10 \% \\
17 \%\end{array}$ & $\begin{array}{r}6 \% \\
11 \%\end{array}$ & $\begin{array}{l}6 \% \\
9 \%\end{array}$ & $\begin{array}{l}11 \% \\
18 \%\end{array}$ & $\begin{array}{l}10 \% \\
19 \%\end{array}$ & $\begin{array}{l}12 \% \\
19 \%\end{array}$ & $\begin{array}{l}11 \% \\
20 \%\end{array}$ & $\begin{array}{l}10 \% \\
18 \%\end{array}$ & $\begin{array}{l}10 \% \\
19 \%\end{array}$ & $\begin{array}{l}11 \% \\
18 \%\end{array}$ & $\begin{array}{l}10 \% \\
19 \%\end{array}$ & $\begin{array}{l}11 \% \\
18 \%\end{array}$ & $\begin{array}{l}17 \% \\
75 \%\end{array}$ & $\begin{array}{l}19 \% \\
29 \%\end{array}$ & $\begin{array}{r}100 \% \\
0 \%\end{array}$ \\
\hline
\end{tabular}

Top: identity percentages
Bottom: homology percentages 


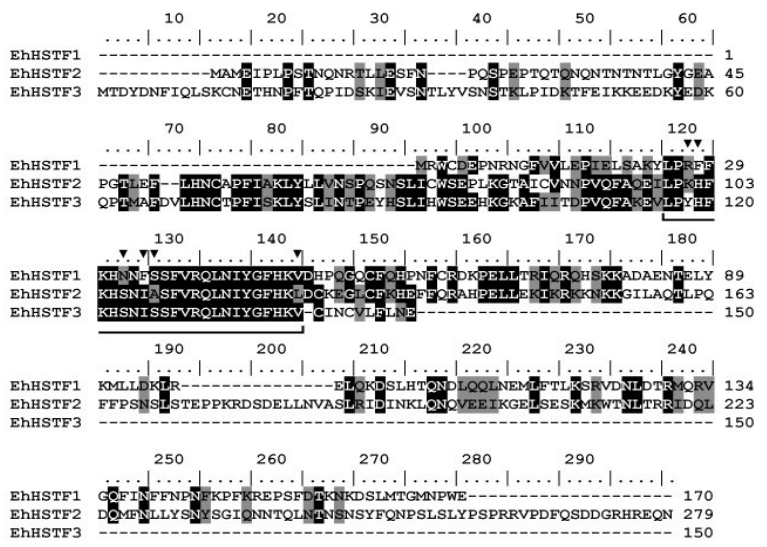

Fig 2: Alignment of the deduced amino acid sequences from the EhHSTFs. Gaps are indicated by dashes. Identical amino acid residues are in black squares. Homologous amino acid residues are in gray squares. Underlined sequence corresponds to the DNA-binding domain. Arrowheads show the amino acid changes in the EhHSTFs DNA-binding domain.

The phylogenetic tree constructed using the alignment of the EhHSTFs and the HSTF from other organisms showed a closer relationship of the EhHSTF2 and EhHSTF3 proteins, while the EhHSTF1 exhibits high similarity with the HSTF1 from $A$. thailiana (Fig 3) and appears to be derive from the same root than the HSTF1 from human, mouse, chicken, frog and fruit fly (Fig 3). However, we can observed that all the HSTF have a common ancestry may be by these reason all these factors present a high similarity in their DNA-binding domain.

These results suggest that the protozoan parasite $E$. histolytica presents at least three putative Ehhstf genes which contains a very conserved DNA-binding domain and that they could also bind to the HSEs located in the gene promoters from this parasite.

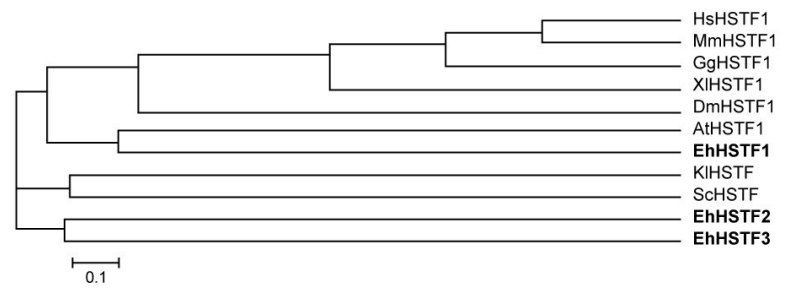

Fig 3: Phylogenetic tree of the DNA-binding domains present in the HSTF. DNA-binding domains from E. histolytica and other organisms were aligned using CLUSTALX1.8 program. The EhHSTFs are in bold face. The phylogenetic tree was then inferred by Neighbor-joining analysis (NEIGHBOR program).
Isolation of the Ehhstf : To demonstrate the physical presence of the Ehhstf genes in the amoeba, we realized different PCR reactions. Briefly, based on the Ehhstf sequences obtained from the screening in the TIGR database from $E$. histolytica, we designed specific oligonucleotides to amplify the entire Ehhstf1, Ehhstf2 and Ehhstf3 genes (see Methods). The PCR reactions were performed using the sense and antisense oligonucleotides specific for each gene previously described and total DNA from the trophozoites of $E$. histolytica as template. As expected a DNA fragments of 510,837 and 459 bp corresponding to the Ehhstfl, Ehhstf2 and Ehhstf3 genes respectively were successfully amplified. These DNA fragments were cloned, sequenced and found to be identical to the assembled sequences (data not shown).

Detection of homologous HSTF in total extracts from $\boldsymbol{E}$. histolytica: "We carried out Western blot assays using total extracts from E. histolytica and heterologous antibodies against anti-human HSTF1 thus in order to identify if some amoeba proteins are recognized by these heterologous antibodies. The results revealed the presence of four bands of 73, 66, 47 and $23 \mathrm{kDa}$ in the total extracts from the trophozoites growth with out heat shock stress. However when the trophozoites were incubated at $42^{\circ} \mathrm{C}$ by different times the intensity of the bands change (Fig 4A). The 73, 47 and $23 \mathrm{kDa}$ peptides increased their intensity particularly when the trophozoites were incubated at $42^{\circ} \mathrm{C}$ by $2 \mathrm{~h}$, whereas the band of $66 \mathrm{kDa}$ was diminishing their intensity according to the increased incubation time. As controls we performed other immunoblottings with the same membrane using other heterologous anti-C/EBP antibodies or the anti-actin from $E$. histolytica. The anti-C/EBP reveals an expected peptide of $65 \mathrm{kDa}$ (Fig 4B) [22], while the anti-actin antibodies reveals also an expected band of $44 \mathrm{kDa}$ (Fig 4C). The results suggest that in the total extracts from E. histolytica are present HSTFs-like, because the heterologous antibodies against the human HSTF1 recognized four peptides.

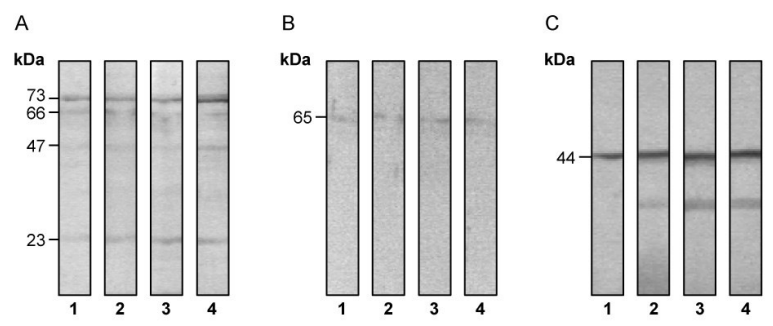

Fig 4: EhHSTF-like detected with the anti-humanHSTF1 on an immunoblot. Lanes 1, total extracts from parasites growth with out heat shock stress; lanes 2 , 3 and 4, total extracts from parasites growth 30,60 and $120 \mathrm{~min}$ at $42^{\circ} \mathrm{C}$ respectively. Immunoblots were performed using anti-human HSTF1 (A), antihuman $\mathrm{C} / \mathrm{EBP} \beta(\mathrm{B})$ and anti-E. histolytica actin (C). 


\section{DISCUSSION}

The cells possess a conserved response to heat shock stress. This response involves the rapid activation of a HSTF, which regulates the transcription of constitutive and stress-inducible mRNA synthesis of various genes. The HSTF is a central regulator for the expression of different proteins during the heat shock response and to exposition to a variety of chemical and physiological stresses. This protein has been identified in different organisms where the role of some of them has been elucidated [30].

In E. histolytica have been described the presence of Hsps [31] and recently have been identified a putative HSEs in the promoters of some genes of this parasite 'unpublished data' suggesting that the amoeba presents a HSTF in their genome. To address this possibility, we performed different alignments, firstably to identify a conserved region in the HSTFs described in other organisms, and this region was the DNAbinding domain. Then, we performed a screening in the Genome Project of $E$. histolytica using this domain as probe. Our analysis revealed the presence of three $h s t f$ genes (Ehhstf1, Ehhstf2, Ehhstf3) in this parasite, as has been documented for human, mouse, chicken and tomato [9-14]. Higher eukaryotic cells possess multiple distinct HSTF isoforms, encoded by different genes. This diversity is further increased through differential splicing, responses to distinct stresses, and preferences for binding to distinct arrangements of HSEs [30]. The existence of multiple HSTF species in any organisms suggest that the HSTF isoforms may have specialized functions that can be triggered by distinct stresses or may activate specific target genes and that the organisms requires of a coordinately co-regulation of different $h s p$ genes [1, 3, 32]. Something similar could be occurring in E. histolytica, since this parasite is exposed to hard ambient conditions as gastric juices, changes in the temperature, $\mathrm{pH}$ and humidity depending of the organ or tissue invaded [33], until the contact with immune system cells and different bacteria species of the intestinal flora. All that situations will be generating the expression or repression of different molecules that permit to the amoeba survive.

On the other hand, the EhHSTFs sequences showed a very conserved DNA-binding domain among the HSTFs cloned from human, mouse, yeasts, frog and plant as A. thailiana. However, this domain in the three EhHSTFs is very short (25 aa) in comparison with the observed in the HSTFs of other organisms $(\approx 106 \mathrm{aa})$.
Additionally, we also observed some differences in this DNA-binding domain in the EhHSTFs. There are six amino acid residues changed, this finding will be implicated in the EhHSTFs affinity, stability and specificity to recognize and bind to the HSEs of different $E$. histolytica promoter genes. Moreover, these punctual differences may allow a wide range of distinct interactions of the DNA-binding domain of the EhHSTFs with the HSEs or other sequences located at the amoeba promoters. In $S$. cerevisiae has been demonstrated that a single amino acid substitution in the DNA-binding domain of yeast HSTF alters the specificity of HSTF on different promoters [34-35]. Despite sequence divergence, that we observed in the alignment of complete amino acid sequences of different HSTFs, all members of the HSTF family have the highly conserved feature: a DNA-binding domain and the EhHSTFs showed these conserved domain.

Conservations of homologous HSTF proteins in organisms as diverse as protozoa, plants, chicken, mouse and human suggest that they could play important and similar roles in the biology of eukaryotes. All that thereby influencing the level of transcriptional activation, and ultimately fine-tunes the nature of the heat shock response and other kind of stresses.

On the other hand, we demonstrate that heterologous antibodies against the human HSTF recognized four bands in total extracts from trophozoites growth with out or with termic stress. Although the molecular weight of the peptides recognized do not precisely correspond to the molecular weight of the predicted EhHSTF, in the literature has been reported that these proteins may occur postranslational modifications as phosphorylation provoking changes in their molecular weights [36]. Perhaps, have been reported that the HSTF requires being homotrimerized to binds to the HSE [37]. In $E$. histolytica we do not know yet if this mechanism also occurs, however under both control and heat shock conditions we observed four proteins, where the 47 and $66 \mathrm{kDa}$ could be homodimers or trimers of these factors.

What is the role of the EhHSTFs? How they control the gene expression in the amoeba?; Why this parasite presents three HSTFs?. These questions require to be answered.

Finally, E. histolytica presents three Ehhstf genes, however, their conclusive inclusion as authentic 
Am. J. Infect. Dis., 3 (2): 115-122, 2007

members would require further functional characterization.

\section{ACKNOWLEDGEMENTS}

This work was supported by SIP-IPN (20061156). We thank Alfredo Padilla for his help in the art work.

\section{REFERENCES}

1. Mathew, A., Y. Shi, C. Jolly and R.I. Morimoto, 2000. Analysis of the mammalian heat-shock response. Inducible gene expression and heatshock factor activity. Methods Mol. Biol., 99: 217-255.

2. Goldberg, A. L., 2003. Protein degradation and protection against misfolded or damaged proteins. Nature. 426: 895-899.

3. Morimoto, R. I., M. P. Kline, D. N. Bimston and J. J. Cotto, 1997. The heat shock response: Regulation and function of heat shock proteins and molecular chaperones. Essays Biochem. 32: 17-29.

4. Trinklein, N. D., J. I. Murray, S. J. Hartman, D. Botstein and R. M. Myers, 2004. The role of heat shock transcription factor 1 in the genome-wide regulation of the mammalian heat shock response. Mol. Biol. Cell. 15: 1254-1261.

5. Wiederrecht, G., D. Seto and C. S. Parker, 1988. Isolation of the gene encoding the $S$. cerevisiae heat shock transcription factor. Cell., 54: 741-853.

6. Gallo, G. J., H. Prentice and R. E. Kinston, 1993. Heat shock factor is required for growth at normal temperatures in the fission yeast Schizosacaromyces pombe. Mol. Cell. Biol., 13: 749-761.

7. Jakobsen, B. K. and H. R. B. Pelham, 1991. A conserved heptapeptide restrains the activity of the yeast heat shock transcription factor. EMBO J. 10: 369-375.

8. Clos, J., J. T. Westwood, P. B. Backer, S. Wilson, K. Lambert and C. Wu, 1990. Molecular cloning and expression of a hexameric Drosophila heat shock factor subject to negative regulation. Cell., 63: 1085-1097.

9. Rabindran, S. K., G. Giogi, J. Clos and C. Wo, 1991. Molecular cloning and expression of a human heat shock factor, HSF1. Proc. Natl. Acad. Sci. USA, 88: 6906-6910.

10. Schuetz, T. J., G. J. Gallo, L. Sheldon, P. Tempst and R. E. Kington, 1991. Isolation of a cDNA for HSF2: evidence for two heat shock factor genes in humans. Proc. Natl. Acad. Sci. USA, 88: 69116915.
11. Nakai, A., M. Tanabe, Y. Kawazoe, J. Inazawa, R. I. Morimoto and K. Nagata, 1997. HSF4, a new member of the human heat shock factor family which lacks properties of a transcriptional activator. Mol. Cell. Biol., 17: 469- 481.

12. Sarge, K. D., V. Zimarino, C. Holm, C. Wo and R. I. Morimoto, 1991. Cloning and characterization of two mouse heat shock factors with distinct inducible and constitutive DNAbonding ability. Genes Dev., 5: 1902-1911.

13. Nakai, A. and R. I. Morimoto, 1993. Characterization of a novel chicken heat shock transcription factor, heat shock factor 3, suggests a new regulatory pathway. Mol. Cell. Biol. 13: 1983-1997.

14. Scharf, K. D., S. Rose, W. Zott, F. Schoffl, L. Nover and F. Scoff, 1990. Three tomato genes code for heat stress transcription factors with a region of remarkable homology to the DNAbinding domain of the yeast HSF. EMBO J., 9: 4495-4501.

15. Baniwal, S. K., K. Bharti, K. Y. Chan, M. Fauth, A. Ganguli, S. Kotak, S. K. Mishra, L. Nover, M. Port, K. D. Scharf, J. Tripp, C. Weber, D. Zielinski and P. von Koskull-Doring. 2004. J. Biosci. 29: 471-487.

16. Gómez, C., G. Pérez, E. López-Bayghen, and E. Orozco, 1998. Transcriptional analysis of the EhPgpl promoter of Entamoeba histolytica multidrug resistant mutant. J. Biol. Chem., 273: 7277-7284.

17. Pérez, G., C. Gómez, E. López-Bayghen, E. Tannich and E. Orozco, 1998. Transcriptional analysis of the EhPgp5 promoter of Entamoeba histolytica multidrug resistant mutant. J. Biol. Chem., 273: 7285-7292.

18. Nieto, A., D. Pérez, E. Orozco, F. Paz and C. Gómez, 2005. Entamoeba histolytica EhPgp5 transcriptional activation depends on putative emetine response elements. Exp. Parasitol., 110: 233-237.

19. Buß, H., C. Lioutas, S. Dobinsky, R. Nickel and E. Tannich, 1995. Analysis of the 170-kDa lectin gene promoter of Entamoeba histolytica. Mol. Biochem. Parasitol., 72: 1-10.

20. Ortiz, D., M. del Carmen Domínguez-Robles, N. Villegas-Sepúlveda and I. Meza, 2000. Actin induction during PMA and cAMP-dependent signal pathway activation in Entamoeba histolytica trophozoites. Cell Microbiol., 2: 391400 . 
21. Purdy, J. E., L. T. Pho, B. J. Mann and W. A. Jr. Petri, 1996. Upstream regulatory elements controlling expression of the Entamoeba histolytica lectin. Mol. Biochem. Parasitol., 78: 91-103.

22. Marchat, L. A., C. Gomez, D. G. Perez, F. Paz, L. Mendoza, and E. Orozco, 2002. Two CCAAT/enhancer binding protein sites are cisactivator elements of the Entamoeba histolytica EhPgpl (mdr-like) gene expression. Cell Microbiol., 4(11): 725-737.

23. Singh, U., and J. B. Roggers, 1998. The novel core promoter element GAAC in the $h g l 5$ gene of Entamoeba histolytica is able to direct a transcription start site independent of TATA or initiator regions. J. Biol. Chem., 273: 2166321668.

24. Schaenman. J. M., P. C. Driscoll, J. W. Hockensmith, B. J. Mann and W. A. Jr. Petri, 1998. An upstream regulatory element containing two nine basepair repeats regulates expression of the Entamoeba histolytica hgl5 lectin gene. Mol. Biochem. Parasitol., 94: 309-313.

25. De Dios-Bravo G., G. Luna-Arias, A. Riverón, J. Olivares-Trejo, C. López-Camarillo and E. Orozco, 2005. Entamoeba histolytica TATA-box binding protein binds to different TATA variants in vitro. FEBS J., 272: 1354-1366.

26. Schaenman, J., C. Gilchrist, B. Mann and W. Jr. Petri, 2001. Identification of two Entamoeba histolytica sequence-specific URE4 enhancerbinding proteins with homology to the RNAbinding motif RRM. J. Biol. Chem., 276 (2): 1602-1609.

27. Mendoza, L., E. Orozco, M. A. Rodríguez, G. García-Rivera, T. Sánchez, E. García and P. Gariglio. 2003. Ehp53, an Entamoeba histolytica protein, ancestro of the mammalian tumour supresor p53. Microbiology. 149(Pt4): 885-893.

28. Diamond, L. S., R. Harlow and C. Cunnink, 1978. A new medium for the axenic cultivation of Entamoeba histolytica and other Entamoeba Transaction of the Royal Society of Tropical Medicine and Hygiene, 72: 431-432.

29. Bradford, M. M., 1976. A rapid sensitive method for the quantitation of microgram quantities of protein utilizing the principle of protein-dye binding. Analytical Biochemistry, 2: 248-254.
30. Pirkkala, L., P. Nykanen and L. Sistonen, 2001. Roles of the heat shock transcription factors in regulation of the heat shock response and beyond. FASEB J, 15: 1118-1131.

31. Bernes, S., R. Siman-Tov and S. Ankri, 2005. Epigenetic and classical activation of Entamoeba histolytica heat shock protein 100 (Ehsp100) expression. FEBS Letters, 579: 6395-6402.

32. Hashikawa, N. and H. Sakurai, 2004. Phosphorylation of the yeast heat shock transcription factor is implicated in gene-specific activation dependent on the architecture of the heat shock element. Mol. Cell. Biol., 24(9): 36483659.

33. Espinosa-Cantellano, M. and A. MartínezPalomo. 2000. Pathogenesis of intestinal amebiasis: from molecules to disease. Clin. Microbiol. Rev., 13: 318-331.

34. Santoro, N., N. Johansson and D. J. Thiele, 1998. Heats hock element architecture is a important determinant in the temperature and transactivation domain requirements for heat shock transcription factor. Mol. Cell. Biol., 18(11): 6340-6352.

35. Silar, P., G. Butler and D. J. Thiele, 1991. Heat shock transcription factor activates transcription of the yeast metallothionein gene. Mol. Cell. Biol., 11: 1232-1238.

36. Hashikawa, N., Y. Mizukami, H. Imazu and H. Sakurai. 2006. Mutated yeast heat shock transcription factor activates transcription independently of hyperphosphorylation. J. Biol. Chem., 281: 3936-3942.

37. Sarge, K. D., S. P. Murphy and R. I. Morimoto. 1993. Activation of heat shock gene transcription by heat shock factor 1 involves oligomerization, acquisition of DNA-binding activity, and nuclear localization and can occur in the absence of stress. Mol. Cell. Biol., 13: 1392-1407. 